\title{
Prediksi Utang Luar Negeri Indonesia dengan Menganalisis Cadangan Devisa terhadap Nilai Ekspor Indonesia Periode Tahun 2003 - 2016
}

\author{
R. Rudi Alhempi ${ }^{1 *}$; Dodi Irawan Siregar ${ }^{1}$
}

\section{INFO A RTIKEL}

\section{Penulis:}

${ }^{1}$ Program Studi Manajemen, STIE Persada Bunda, Pekanbaru, Indonesia

*E-mail: rudi.alhempi@gmail.com

Untuk mengutip artikel ini:

Alhempi RR \& Siregar DI 2017, 'Prediksi utang luar negeri indonesia dengan menganalisis cadangan devisa terhadap nilai ekspor indonesia periode tahun 2003 - 2016', Jurnal Ekonomi KIAT. vol. 30. no. 1. hal. 29-31.

\begin{tabular}{l} 
Akses online: \\
www.jurnalkiatuir.com \\
E-mail: \\
kiat@journal.uir.ac.id \\
\hline Di bawah lisensi: \\
$\begin{array}{l}\text { Creative Commons Attribute- } \\
\text { ShareAlike } 4.0 \quad \text { International } \\
\text { Licence }\end{array}$
\end{tabular}

Akses online:

E-mail:

Di bawah lisensi:

ShareAlike $\quad 4.0 \quad$ International

\section{Pendahuluan}

Pada masa krisis ekonomi, utang luar negeri Indonesia, termasuk utang luar negeri pemerintah dan swasta, telah meningkat drastis dalam hitungan rupiah. Sehingga, menyebabkan pemerintah Indonesia harus menambah utang luar negeri yang baru untuk membayar utang luar negeri yang lama yang telah jatuh tempo. Akumulasi utang luar negeri dan bunganya tersebut akan dibayar melalui APBN RI dengan cara mencicilnya pada tiap tahun anggaran. Hal ini menyebabkan berkurangnya kemakmuran dan kesejahteraan rakyat pada masa mendatang, sehingga jelas akan membebani masyarakat Indonesia. Dalam jangka pendek, utang luar negeri sangat membantu pemerintah Indonesia dalam upaya menutup defisit anggaran pendapatan dan belanja negara, akibat pembiayaan pengeluaran rutin dan pengeluaran pembangunan yang cukup besar. Dengan demikian, laju pertumbuhan ekonomi dapat dipacu sesuai dengan target yang telah ditetapkan sebelumnya.

Tetapi dalam jangka panjang, ternyata utang luar negeri pemerintah tersebut dapat menimbulkan berbagai persoalan ekonomi di Indonesia (Atmaja A. S, 2000). Bagaimana cara menjaga utang Indonesia tidak menghadapi risiko besar sehingga mampu untuk dilunasi? Caranya adalah dengan menjaga cadangan devisa. Cadangan devisa, selain digunakan sebagai menjaga stabilitas rupiah juga digunakan untuk membayar utang luar negeri pemerintah. Menggunakan cadangan devisa untuk menjaga rupiah. Dengan cadangan devisa kita yang tinggi, berarti kita punya kemampuan untuk membayar utang (Faisal M, 2019).

Untuk bisa mendatangkan devisa, pemerintah tidak hanya bisa dapat mengandalkan valas alias pasar valuta asing saja. Di sisi lain pemerintah harus dapat memperkuat neraca transaksi berjalan. Caranya dengan meningkatkan pendapatan transaksi berjalan atau current account receipts yakni pendapatan yang berasal dari ekspor barang dan jasa dan ekspor sumber daya alam lainnya baik itu migas dan nonmigas.

\section{Metode Penelitian}

\subsection{Jenis dan pendekatan penelitian}

Penelitian ini termasuk Penelitian Explanatory Research dengan pendekatan Kuantitatif, dengan menggunakan metode analisis linear berganda disebabkan variabel bebasnya lebih dari satu. Variabel yang mempengaruhi disebut independen variabel (variabel bebas) dan variabel yang dipengaruhi disebut dependen variabel (variabel terikat) 


\subsection{Variabel dalam pengukuran}

Penelitian ini terdiri dari dua variabel bebas yaitu Nilai Ekspor Indonesia ke Luar Negeri $\left(X_{1}\right)$ dan Cadangan Devisa Republik Indonesia $\left(\mathrm{X}_{2}\right)$, sedangkan variabel terikat adalah Utang Luar Negeri Indonesia disingkat dengan Varibel (Y).

\subsection{Sumber data}

Sumber data yang digunakan adalah sumber data sekunder yaitu sumber data penelitian yang diperoleh secara tidak langsung melalui media perantara atau badan/instansi terkait (Indriantoro, 1999). Dalam hal ini peneliti mengambil data dari Badan Pusat Statistik tahun 2017 mengenai Nilai Ekspor Indonesia, cadangan devisa Indonesia dan utang luar negeri Indonesia di BPS Indonesia 2017.

\subsection{Teknik pengumpulan data}

Teknik pengumpulan data yang dilakukan untuk mendapatkan data yang relevan dari permasalahan yang diteliti adalah melalui studi kepustakaan (Library Research), yaitu dengan cara membaca dan mempelajari literatur yang terdapat diperpustakaan, dengan maksud untuk menempatkan landasan teoritis mengenai masalah pokok yang sedang dibahas.

\section{Hasil Penelitian dan Pembahasan}

\subsection{Hasil analisis data}

Penelitian ini meprediksi dan meramalkan posisi Utang Luar Negeri Indonesia di masa datang dengan mengolah dan menganalisis data dimasa lalu, sebagai variabel dependen (terikat), adalah Nilai Ekspor Indonesia ke luar.

Analisis regresi linear berganda dengan variabel terikat (dependen) adalah Utang Luar Negeri Indonesia disingkat dengan (Y), dan variabel bebas (independen) adalah Cadangan Devisa Indonesia
$\left(\mathrm{X}_{1}\right)$, dan Nilai Ekspor Indonesia sebagai $\left(\mathrm{X}_{2}\right)$. Data dari variabel-variabel diatas adalah sebagai berikut :

Tabel 1. Data utang luar negeri Indonesia (Y), cadangan devisa Indonesia $\left(\mathrm{X}_{1}\right)$ dan nilai ekspor Indonesia $\left(\mathrm{X}_{2}\right)$

\begin{tabular}{crrr}
\hline Tahun & $\mathbf{X}_{\mathbf{1}}$ & $\mathbf{X}_{\mathbf{2}}$ & \multicolumn{1}{c}{$\mathbf{Y}$} \\
\hline 2003 & 36.3 & 61.1 & 86657 \\
2004 & 36.3 & 71.6 & 87492 \\
2005 & 34.7 & 85.7 & 82431 \\
2006 & 42.6 & 100.8 & 78595 \\
2007 & 56.9 & 114.1 & 141180 \\
2008 & 51.6 & 137 & 155080 \\
2009 & 66.1 & 116.5 & 172871 \\
2010 & 96.2 & 157.8 & 202413 \\
2011 & 110.1 & 203.5 & 225375 \\
2012 & 112.8 & 190 & 252364 \\
2013 & 99.4 & 182.6 & 266109 \\
2014 & 111.9 & 176 & 293328 \\
2015 & 105.9 & 150.4 & 310730 \\
2016 & 116.4 & 145.2 & 316407 \\
\hline
\end{tabular}

Sumber: Badan Pusat Statistik Indonesia (2017)

Dalam suatu penelitian saat tahap menganalisis data, regresi linear berganda merupakan pengembangan dari regresi linear sederhana, yaitu dapat digunakan untuk melakukan prediksi permintaan dimasa yang akan datang berdasarkan analisis data dimasa lalu atau untuk mengetahui pengaruh satu atau lebih variabel bebas terhadap satu variabel tak bebas yang digunakan. Penerapan metode berganda jumlah variabel bebas yang digunakan lebih dari satu yang mempengaruhi variabel tak bebas independent (Siregar S, 2012).

Dari Tabel 1 didapat persamaan regresi linear berganda dengan dua prediktor. Memulainya dengan membuat tabel penolong sebagai berikut:

Tabel 2. Data penolong untuk mencari persamaan regresi linear berganda yaitu nilai konstanta $b_{1}$ dan $b_{2}$

\begin{tabular}{|c|c|c|c|c|c|c|c|c|c|}
\hline & $X_{1}$ & $\mathbf{X}_{2}$ & $\mathbf{Y}$ & $\mathrm{X}_{1}^{2}$ & $\mathbf{X}_{2}^{2}$ & $\mathbf{Y}^{2}$ & $\mathbf{X}_{1} \mathbf{Y}$ & $\mathbf{X}_{2} \mathbf{Y}$ & $\mathbf{X}_{1} \mathbf{X}_{2}$ \\
\hline 2003 & 36.3 & 61.1 & 7 & 131769 & 3733.21 & 9 & 1.5 & & \\
\hline 2004 & 6.3 & & 92 & & 56 & & & & \\
\hline 2005 & & & & & & & & & \\
\hline 2006 & 42.6 & 0.8 & 78595 & & 010 & 4025 & 147 & 2376 & 94.08 \\
\hline 2007 & 56.9 & & & & & & & & \\
\hline 2008 & 516 & 137 & 5080 & 26 & 18769 & 2404 & & 960 & 7069.2 \\
\hline 2009 & 66.1 & 6.5 & 871 & & 25 & 2988 & .1 & 1.5 & 7700.65 \\
\hline 2010 & 96.2 & 7.8 & -1 & & 2490 & 40971 & 17 & 3194 & 5180.36 \\
\hline 2011 & 0.1 & 03.5 & 375 & 01 & 25 & 50 & 5 & 2.5 & 2405.35 \\
\hline & & 190 & & 04 & 36100 & & & 47 & 21432 \\
\hline 3 & 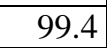 & 82.6 & 9 & & 342.76 & & & 3.4 & 18150.44 \\
\hline & & 70 & & & & & 3282 & 728 & 19694.4 \\
\hline & 5.9 & 0.4 & 9730 & & 2620.16 & 32900 & 32 & 792 & 5927.36 \\
\hline 2016 & 116.4 & 145.2 & & & & & 36829774.8 & 45942296.4 & \\
\hline 2 & 077.2 & 92.3 & 71032 & 9718 & 32160.01 & $6.10977 \mathrm{E}+11$ & 41755451.4 & 02687015.8 & 8.21 \\
\hline
\end{tabular}

Sumber: Badan Pusat Statistik Indonesia (2017) 


\subsection{Tingkat korelasi regresi linear berganda}

Dari analisis tingkat korelasi regresi linear berganda persamaan Utang Luar Negeri Indonesia Dengan Menganalisis Cadangan Devisa Terhadap Nilai Ekspor Indonesia dari Tahun 2003 - 2016. Dengan interpretasi adalah sangat kuat yaitu berkisar antara 0,75 sampai 0,99 .

\subsection{Uji linearitas (uji-f) regresi berganda}

Berdasarkan hasil olahan data, $\mathrm{f}_{\text {hitung }}>\mathrm{f}_{\text {tabel }}$ yaitu: 61,25233963 > 3,98 Maka, Ho ditolak. Jadi, Analisis Regresi Linear Berganda dapat digunakan dalam Utang Luar Negeri Indonesia Dengan Menganalisis Cadangan Devisa Terhadap Nilai Ekspor Indonesia dari Tahun 2003 - 2016.

Hasil analisis regresi linear berganda didapat persamaan Utang Luar Negeri Indonesia Dengan Menganalisis Cadangan Devisa Terhadap Nilai Ekspor Indonesia dari Tahun 2003 - 2016. Maka didapat rumus persamaan regresi linear berganda adalah sebagai berikut :

$$
Y=16167.1066+3131.2208 X_{1}-489.975 X_{2}
$$

Dengan menggunakan persamaan diatas kita dapat memprediksi Utang Luar Negeri Indonesia Dengan Menganalisis Cadangan Devisa Terhadap Nilai Ekspor Indonesia dari Tahun 2003 - 2016.

\subsection{Uji pengaruh parsial (uji-t)}

Yaitu, menentukan apakah ada pengaruh secara parsial antara Cadangan Devisa Indonesia (X1) dengan Utang Luar Negeri Indonesia (Y) dan apakah ada pengaruh secara parsial Nilai Ekspor Indonesia (X2) dan Utang Luar Negeri Indonesia (Y).

Berdasarkan perolehan data yang telah diolah, $\mathrm{t}_{1}$ hitung $>\mathrm{t}_{\text {tabel }}=15.52897093>2,178$, maka $\mathrm{H}_{\mathrm{o}}$ ditolak artinya, terdapat pengaruh yang besar

\section{Referensi}

Abdul M, 2017, Realitas Sistem Perbankan Syari'ah dan Ekonomi Islam, Jurnal Masharif al-Syariah: Jurnal Ekonomi dan Perbankan Syariah/Vol. 2, No. 1, 2017

Akdon dan Ridwan. 2013. Rumus dan Data dalam Analisis Statistika. Bandung: Alfabeta

Atmadja A. S, 2000. Utang Luar Negeri Indonesia Perkembangan dan Dampaknya. Jurnal Ekonomi Akuntansi, Fakultas Ekonomi - Universitas Kristen Petra. Vol. 2, No. 1, Mei 2000: 83 - 94.

Draper, N., H. Smith. 1992. Analisis Regresi Terapan Edisi Kedua.Terjemahan oleh Bambang Sumantri. Gramedia Pustaka Utama, Jakarta

Faisal M. 2019. Strategi Ini Bisa Dipakai Pemerintah Lunasi Utang Luar Negeri. JawaPos.https://www.jawapos.com/ekonomi/17/ 03/2018/strategi-ini-bisa-dipakai-pemerintahlunasi-utang-luar-negeri.

Indriantoro, nurdan Supomo, bambang (1999). Metodologi Penelitian Bisnis Untuk Akuntansi \& Manajemen. Yogyakarta : Penerbit BPFE. (signifikan) secara parsial antara cadangan devisa dan utang luar negeri.

Untuk $\mathrm{t}_{2}$ hitung $\leq \mathrm{t}_{\text {tabel }}$ yaitu $-1.273682125 \leq$ 2,178 maka Ho ditolak artinya, tidak terdapat pengaruh yang besar (signifikan) secara parsial antara nilai ekspor terhadap utang luar negeri.

\section{Simpulan}

Dari hasil penelitian dapat disimpulkan data statistika dengan variabel-variabel Prediksi Utang Luar Negeri Indonesia Dengan Menganalisis Cadangan Devisa Terhadap Nilai Ekspor Indonesia dari Tahun 2003 2014 adalah sebagai berikut :

1) $\mathrm{f}_{\text {hitung }}>\mathrm{f}_{\text {tabel }}$ yaitu 61,252 > 3,98 Maka, Ho ditolak. Jadi, Analisis regresi linear dapat digunakan dalam memprediksi Utang Luar Negeri Indonesia Dengan Menganalisis Cadangan Devisa Terhadap Nilai Ekspor Indonesia dari Tahun 2003 $-2014$.

2) Persamaan Regresi Linear Berganda adalah sebagai berikut:

$$
Y=16167.1066+3130.2208 X_{1}-489.975 X_{2}
$$

3) Korelasi (keterkaitan) antara hubungan Utang Luar Negeri Indonesia Dengan Menganalisis Cadangan Devisa Terhadap Nilai Ekspor Indonesia dari Tahun 2003 - 2016 diperoleh hasil 0,957917473 dengan interpretasi adalah sangat kuat yaitu berkisar antara 0,75 sampai 0,99.

4) Jadi, $t_{1 \text { hitung }}>t_{\text {tabel }}=15.52897093>2,178$; maka Ho ditolak artinya, terdapat pengaruh yang besar (signifikan) secara parsial antara cadangan devisa dan utang luar negeri.

5) Untuk $\mathrm{t}_{2 \text { hitung }} \leq \mathrm{t}_{\text {tabel }}$ yaitu $-1.273682125 \leq 2,178$ maka Ho ditolak artinya, tidak terdapat pengaruh yang besar (signifikan) secara parsial antara nilai ekspor terhadap utang luar negeri.

Kelley, W. D., and Jr. Ratliff, T.A., Nenadic, C. 1992. Basic Statistics for laboratories, a primer for laboratory worker. Van nostrand reinhold, new York.

Kutner, M.H., C.J. Nachtsheim., dan J. Neter. 2004. Applied Linear Regression Models. 4th ed. New York: McGraw-Hill Companies, Inc.

Merriam-Webster's. 2003. Collegiate Dictionary. 11th ed. 2003. United States of America. MerriamWebster,Inc. 2003. hal 441

Deresky, Helen. 2006. International Management. 4th ed. United States of America. Addison - Wesley. Hal 237

Mankiw, Gregory. 2006. Pengantar Ekonomi Makro, Edisi Ketiga, Salemba Empat Jakarta.

Samuelson, Paul A. \& Nordhaus, William D. 2004. Ilmu Makro ekonomi. Edisi Bahasa Indonesia, Jakarta: PT Media Global Edukasi.

Siregar, S. 2012. Statistik Parametrik untuk Penelitian Kuantitatif, Cetakan Pertama, Jakarta: PT Bumi Aksara 